\title{
THE IMPORTANCE OF \\ ORGANIZATIONAL CULTURE FOR HUMANITARIAN OPERATIONS
}

\author{
Nikola Milošević ${ }^{1}$, Milan Mišićc ${ }^{2}$ Nemanja Matić ${ }^{3}$ \\ ${ }^{1}$ RMHK Trepča A.D., Zvečan \\ ${ }^{2}$ Academy of Vocational Studies of Kosovo and Metohija, Leposavić \\ ${ }^{3}$ Delikos DOO, Sopot
}

Corresponding: nikolamilosevic1@yahoo.com

Review article

Received: 13.03.2021; Accepted: 07.05.2021

\begin{abstract}
The humanitarian setting poses a number of challenges to organizations, so it is important to respond in an adequate way. Organizational culture is a significant factor in organizational performance and can be a deciding factor between success and failure. Every organization has its own unique culture, whether management is aware of it or not. In order to perform in the most efficient way and to be able to carry the strategy into effect properly, humanitarian organizations need an adequate and strong organizaional culture. Then, to strengthen the team's sense of purpose and help it move in a unified direction humanitarian principles and standards are developed. For the development of the organization timely establishment of value systems and patterns of behavior is very important. Organizational culture is important for internal structure as well as for external bonds among participants.
\end{abstract}

Keywords: organizational culture, humanitarian organization, cooperation, humanitarian operations.

\section{Introduction}

Every organization in the world has its own organizational culture, whether aware of it or not. Culture is an important factor when it comes to employee and manage-ent behavior, as well as the connection among them. Organizational cul- ture is found to be applicable in every business around the globe but the types of cultures would differ. An organization's culture has an impact on both their work lives as well as their personal lives. Timely establishment of value systems and patterns of behavior is very important for the development 
Milošević $N$. et al., The Importance of Organizational Culture for Humanitarian Operations

of the organization. The importance of organizational culture even nowadays can be overlooked. Some organizations don't take it seriously, and if not taken seriously side effects could be triggered. Thus, if leaders understand the culture the right way, the organization's goals and objectives can be achieved more efficiently. Otherwise, if not, the culture can become an obstacle towards the organization's best performance. Nonprofit organizations as well need to take care of organizational culture. If they fail to recognize culture's important role, the ability to complete the mission they are created for in the first place is endangered. This is especially important for humanitarian organizations because their aim and purpose are specific. Also, the role those organizations have is unique and requires a different approach.

This paper consists of four parts, where each of them shows the importance of organizational culture. The paper findings show that organizational culture has a significant role in humanitarian response efforts and the overall humanitarian functioning.

\section{Organizational culture}

Organizational culture is a significant factor in organizational performance and can be a deciding factor between success and failure. According to Schwartz \& Davis [1981] culture is a pattern of beliefs and expectations shared by the organization's members that create norms that powerfully shape the behavior of individuals and groups in the organization. Culture is the system of such publicly and collectively accepted meanings operating for a given group at a given time [Pettigrew, 1979]. Schein [2004] defines organizational culture as "a pattern of shared basic assumptions, invented, discovered, or developed by a given group, as it learns to cope with its problems of external adaptation and internal integration, that has worked well enough to be considered valid, and therefore is to be taught to new members of the group as the correct way to perceive, think, feel in relation to those problems". Other authors give similar definitions of organizational culture. Robbins \& Coulter [2005] describe organizational culture as the shared values, beliefs, or perceptions held by employees within an organization or organizational unit. Because organizational culture reflects the values, beliefs, and behavioral norms that are used by employees in an organization to give meaning to the situations that they encounter, it can influence the attitudes and behavior of the staff. [Scott-Findlay \& Estabrooks, 2006] 
Schein [2004] describes three levels of organizational culture as it's shown within figure 1:

1. Visible organizational structures and processes (hard to decipher) such as the architecture of its physical environment; its language; its technology and products; its artistic creations; its style, as embodied in clothing, manners of address, emotional displays, and myths and stories told about the organization; its published lists of values; its observable rituals and ceremonies; and so on.
2. Strategies, goals, philosophies (espoused justifications). A set of beliefs and values that become embodied in an ideology or organizational philosophy thus can serve as a guide and as a way of dealing with the uncertainty of intrinsically uncontrollable or difficult events.

3. Unconscious, taken-for-granted beliefs, perceptions, thoughts, and feelings, and so on (ultimate source of values and action). Basic assumptions, like theories-inuse, tend to be nonconfrontable and nondebatable, and hence are extremely difficult to change

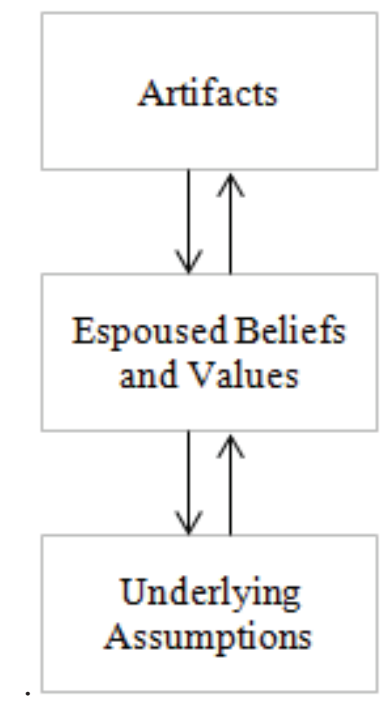

Figure 1. Levels of culture

Organizational culture, among oth- ${ }^{-}$members; (3) foster a shared rather ers, serves to (1) set boundaries bethan individual commitment; (4) tween one organization and others, enhance social stability, and (5) be (2) foster a sense of identity for its the mechanisms for the creation of 
Milošević $N$. et al., The Importance of Organizational Culture for Humanitarian Operations

meaning and control that guide and shape the attitudes and behaviors of members of the organization. [Robbins \& Judge, 2012]

Every organization is characterized by its own unique culture, sometimes management and employees are aware of it sometimes they are not. So it is important to identify the organizational culture as early as possible in order to influence the development of the culture. To determine the type of organizational culture the Organizational Culture Assessment Instrument (OCAI) is developed by Cameron \&
Quinn [2006]. This instrument helps define the organizational culture type based on a typology matrix. OCAI uses six dimensions to develop the organizational culture type. They are (a) dominant characteristics, (b) organizational leadership, (c) management of employees, (d) organizational glue, (e) strategic emphases, and (f) criteria of success. The OCAI, therefore, is an instrument that allows you to classify the organization into one of the four categories: hierarchy, market, clan, and adhocracy culture. These categories are shown in figure 2 .

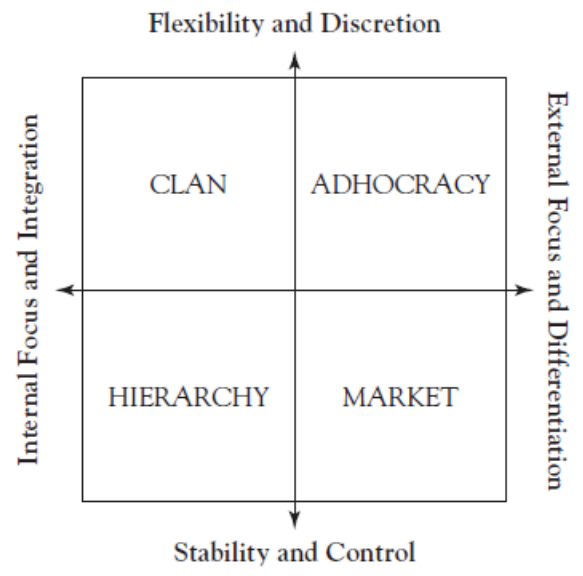

Figure 2. The competing values framework

The collective acceptance and submission to the values, standards, attitudes, and behavior patterns will have a positive impact on the set of elements of the organizational culture mutually perceived and shared by the employees, which will make it stronger. [Szczepańska
\& Kosiorek, 2017] This definition emphasizes the importance of accepting the culture by employees.

The Cultural Web identifies six interrelated elements that help to make up the "paradigm" - the pattern or model - of the work environment. By analyzing the factors in 
each, it is possible to see the bigger picture organization's culture: what is working, what isn't working, and what needs to be changed. The six elements shown in figure 3 are: [Johnson et al., 2012]

- Stories - The past events and people talked about inside and outside the organization. Who and what the organization chooses to immortalize says a great deal about what it values, and perceives as great behavior.

- Rituals and Routines - The daily behavior and actions of people that signal acceptable behavior. This determines what is expected to happen in given situations, and what is valued by management.

- Symbols - The visual representations of the organization including logos, how plush the offices are, and the formal or informal dress codes.
- Organizational Structure - This includes both the structure defined by the organization chart, and the unwritten lines of power and influence that indicate whose contributions are most valued.

- Control Systems - The ways that the organization is controlled. These include financial systems, quality systems, and rewards (including the way they are measured and distributed within the organization).

- Power Structures - The pockets of real power in the organization. This may involve one or two key senior executives, a whole group of executives, or even a department. The key is that these people have the greatest amount of influence on decisions, operations, and strategic direction.

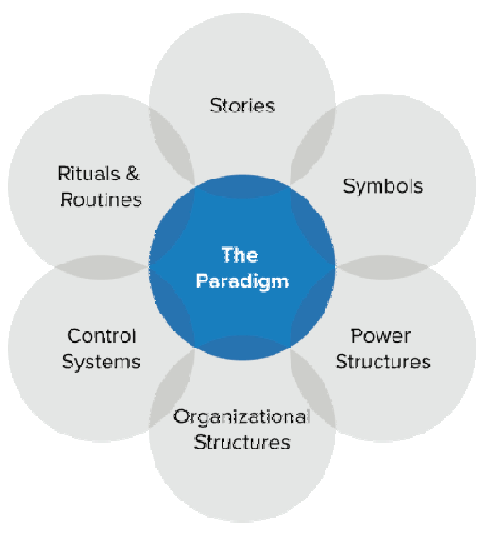

Figure 3. Cultural web model 
It is also necessary to mention the subculture since it is a crucial factor of organizational culture acceptance and stability. The theory sees subculture as a set of understandings or meanings shared by a group of people. [Louis, 1985] It means each culture is divided into different parts, such as levels, branches, professional, regional, national, and other groups. Yet, several different subcultures can coexist within an organization. At least three types of subcultures are conceivable: enhancing, orthogonal, and countercultural (Martin \& Siehl, 1983). Enhancing subculture could respect the values of the dominant culture stronger than the rest of the organization. Orthogonal subculture accepts the values of the dominant culture and their own, non-conflicting set of values. Counterculture is a set of values that could present a direct challenge to the core values of a dominant culture. Although several subcultures could exist it does not mean they are in conflict. Moreover, they can create a synergistic effect and improve the overall performance of the organization.

\section{Organizational culture in humanitarian context}

When emergencies occur good coordination is necessary. Good coordination means delivering assistance by humanitarian organizations timely. The primary goal is to save lives and belongings of beneficiaries. In order to perform in the most efficient way and to be able to carry the strategy into effect properly, humanitarian organizations need an adequate and strong organizational culture. As a humanitarian organization develops from the time of its original incorporation, the attitudes, beliefs, and behavior of its personnel become established and routinized into rules, rituals, values, codes of conduct, and standard operating procedures. [Walkup, 1997] Then, the developed organizational culture is reinforced by newcomers as they accept and enhance it over time. Consequently, the culture can fortify organizational structure and increase permanence through an evolutionary process. Apparently, organizational cultures evolve and change in accordance with environmental factors which affect organizations.

Not only do cultural dynamics influence the internal workings of the organization, they also affect humanitarian organizations' belief systems, behavior, and performance in terms of their relations with: [Walkup, 1997]

- each other (e.g. how HOs engage the politics and logistics of coordination); 
- the state authorities (e.g. how HOs perceive and respond to state attempts to coordinate and regulate $\mathrm{HO}$ operations);

- the affected populations (eg. how personnel communicate and operate with their clients and to what extent HOs incorporate truly participatory approaches to the policy process);

- donors (e.g. how HOs raise funds and negotiate accountability).

Organizational culture is important for humanitarian organizations where, besides employees, plenty of volunteers are present. Humanitarian ambassadors promote the cul- $^{-}$ ture of helping and volunteering as part of organizational culture. Sometimes, they would not be able to spend enough time within the organization to acquire all guidelines properly, but the culture can help to shorten the learning process. Some countries have been developing the culture of volunteering through the education system. Then, it affects their perception, beliefs, and assumptions towards humanitarian awareness. As a consequence, they could be more willing to work as volunteers and could be able to outperform people without a humanitarian background of any sort. Often staff can work long hours in risky and stressful conditions. The sense of purpose developed through organizational culture can help them persist and do their best.

Principles, in classic organizational thinking, precede policy, which in turn precedes implementation. [Hilhorst \& Schmiemann, 2002] To strengthen the team's sense of purpose and help it move in a unified direction humanitarian principles and standards are developed. Organizational principles affect the way humanitarians and volunteers act, think, do their job, make connections and bonds with others in the organization and with external partners. Also, external partners should take those principles into consideration and incorporate them into their culture to be able to work with humanitarians in the most efficient way. Within table 1 can be seen the basic set of principles on which humanitarian organizations rely. The basic principles are humanity, neutrality, impartiality, and independence. Based on the principle of humanity, we affirm the primacy of the humanitarian imperative: that action should be taken to prevent or alleviate $\mathrm{hu}^{-}$ man suffering arising out of disaster or conflict, and that nothing should override this principle. [Sphere, 2018] 
Milošević $N$. et al., The Importance of Organizational Culture for Humanitarian Operations

Table 1. Humanitarian principles

\begin{tabular}{|c|c|}
\hline Red Cross \& Red Crescent & UNOCHA \\
\hline Humanity & Humanity \\
\hline Neutrality & Neutrality \\
\hline Impartiality & Impartiality \\
\hline Independence & Independence \\
\hline Voluntary service & \\
\hline Unity & \\
\hline Universality & \\
\hline
\end{tabular}

The Core Humanitarian Standard on Quality and Accountability (CHS) sets out nine Commitments that organizations and individuals involved in humanitarian response can use to improve the quality and effectiveness of the assistance they provide: [Sphere, 2014]

- Humanitarian response is appropriate and relevant - Communities and people affected by crisis receive assistance appropriate to their needs.

- Humanitarian response is effective and timely - Communities and people affected by crisis have access to the humanitarian assistance they need at the right time.

- Humanitarian response strengthens local capacities and avoids negative effects - Communities and people affected by crisis are not negatively affected and are more prepared, resilient and less at-risk as a result of humanitarian action.

- Humanitarian response is based on communication, participation and feedback - Communities and people affected by crisis know their rights and entitlements have access to information and participate in decisions that affect them.

- Complaints are welcomed and addressed - Communities and people affected by crisis have access to safe and responsive mechanisms to handle com- $^{-}$ plaints.

- Humanitarian response is coordinated and complementary Communities and people affected by crisis receive coordinated, complementary assistance.

- Humanitarian actors continuously learn and improve - Communities and people affected by crisis can expect delivery of 
improved assistance as organizations learn from experience and reflection.

- Staff are supported to do their job effectively and are treated fairly and equitably - Communities and people affected by crisis receive the assistance they require from competent and wellmanaged staff and volunteers.
- Resources are managed and used responsibly for their intended purpose - Communities and people affected by crisis can expect that the organizations assisting them are managing resources effectively, efficiently and ethically.

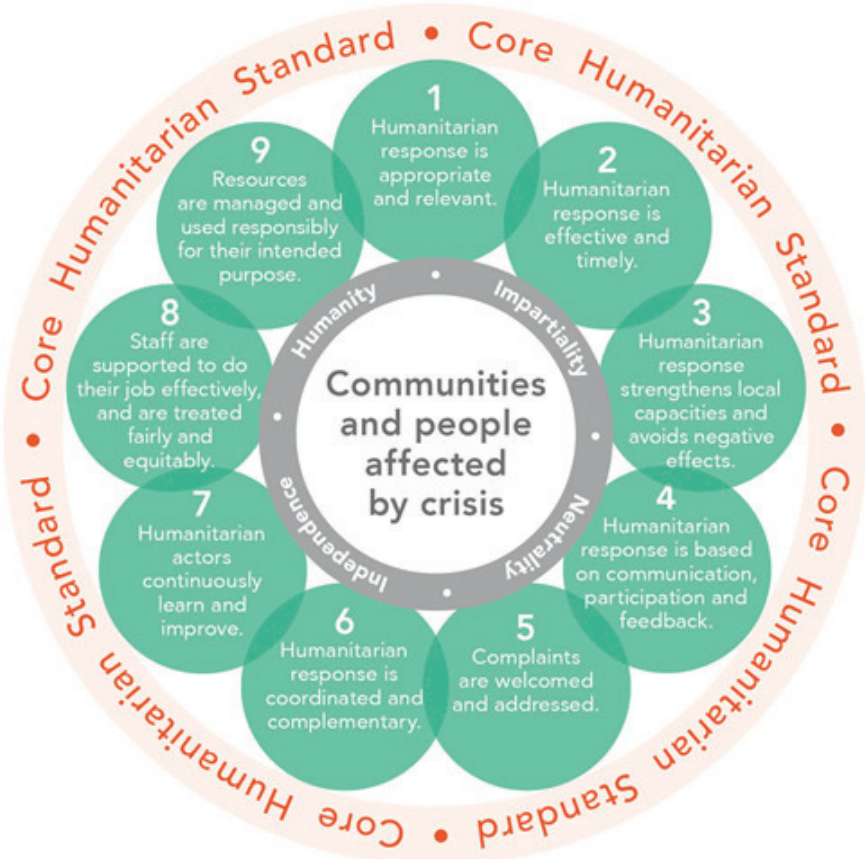

Figure 4. The Core Humanitarian Standard

The Standard is shown in figure 4. It serves as a useful tool for promoting an effective response within an organization and among participants, and for overcoming inconsistency and unpredictability.
Staff is dealing with individuals who are dissimilar to them. Culturally embedded interpretations of and responses to risk are also present among aid organizations. [Johnson et al., 2016] Disaster aid is increasingly globalized, bringing 
together multiple actors whose perceptions, priorities, and modes of working have developed in different cultural contexts [Hewitt 2012]. Thus, misunderstanding, the effectiveness compromising of disaster risk reduction efforts can arise.

Regional and local humanitarian departments are influenced by local culture and by the culture of the parent organization or by the head of the organization. Managers and employees are from the same country or from different countries with different cultural backgrounds. Among employees within an organization conflicts could arise as a consequence of opposite thinking and acting in a variety of different situations, especially on the field. Additionally, subcultures can emerge as a consequence of national culture disparity. Also, the risk is another potential point of conflict. Various groups perceive risk differently. Reasons may vary, but the most common are life experience, cultural background, and education. [Cohn et al., 1995; Renn \& Rohrmann, 2000; Righi et al., 2021] External actors may project their cultural biases on communities and bypass existing social arrangements, distributing aid in a way that is inequitable and culturally irrelevant. [Kruks-Wisner, 2010]

Hofstede et al. [1990] found that the effect of the national context on individual employees affects organizational cultures. Thus, an entire department in a country is consisted of domestic employees, which behavior can be driven by values they acquired through their domestic national culture. Therefore, Kwantes \& Boglarsky [2004] showed that occupation affects perspectives on desired organizational culture. Additionally, local cultures can determine the way citizens from areas with high disaster risk perceive and understand the potential disaster occurrence. For instance, attitudes related to explanations of natural hazards, particularly earthquakes, have been found to be a major obstacle to disaster risk prevention in some Muslim communities by citizens disregarding building standards and community education programs. [Paradise, 2005] On the contrary, citizens in religious South Italy (Mount Etna region) were taking part in activ ${ }^{-}$ ities that are believed to help miracles take place but, simultaneously, they engaged in protective measures such as evacuation. [Chester et al., 2008] These results demonstrate that cultural factors such as religious beliefs with the specific local context, do affect disaster-related behavior.

The influence of national culture on organizational culture is mostly visible in: [Sikorski, 2003] 
- the communication in the organization - meaning the level of openness and formality of this process, how extrovert it is, and whether it is possible to show emotions,

- leadership - especially the sources of power and the ways of exercising it, the proximity or distance in the hierarchy, the level of the employees' participation in the decision-making process, the feeling of community,

- motivation - the pressure to achieve results, competition, the acceptance of uncertainty, the care for the quality of interpersonal relations, the evaluation of individuals and groups, providing safety,

- the organization model - especially the level of the standard- ization of work, processes and skills, structure, and ways of $\mathrm{ex}^{-}$ ercising control.

To show the importance of healthy and strong organizational culture, an example of an organizational structure of UNHCR is depicted in figure 5 . As it can be seen the organization has a complex structure. This type of organization is a global organization with a multitude of departments and regional offices. Every organization like UNHCR should be well managed and improved. To achieve so there should be established and fostered a culture that strengthens the bonds among employees both between departments and countries' offices. Organizational culture helps employees better understand the aim organization is trying to achieve. 
Milošević $N$. et al., The Importance of Organizational Culture for Humanitarian Operations

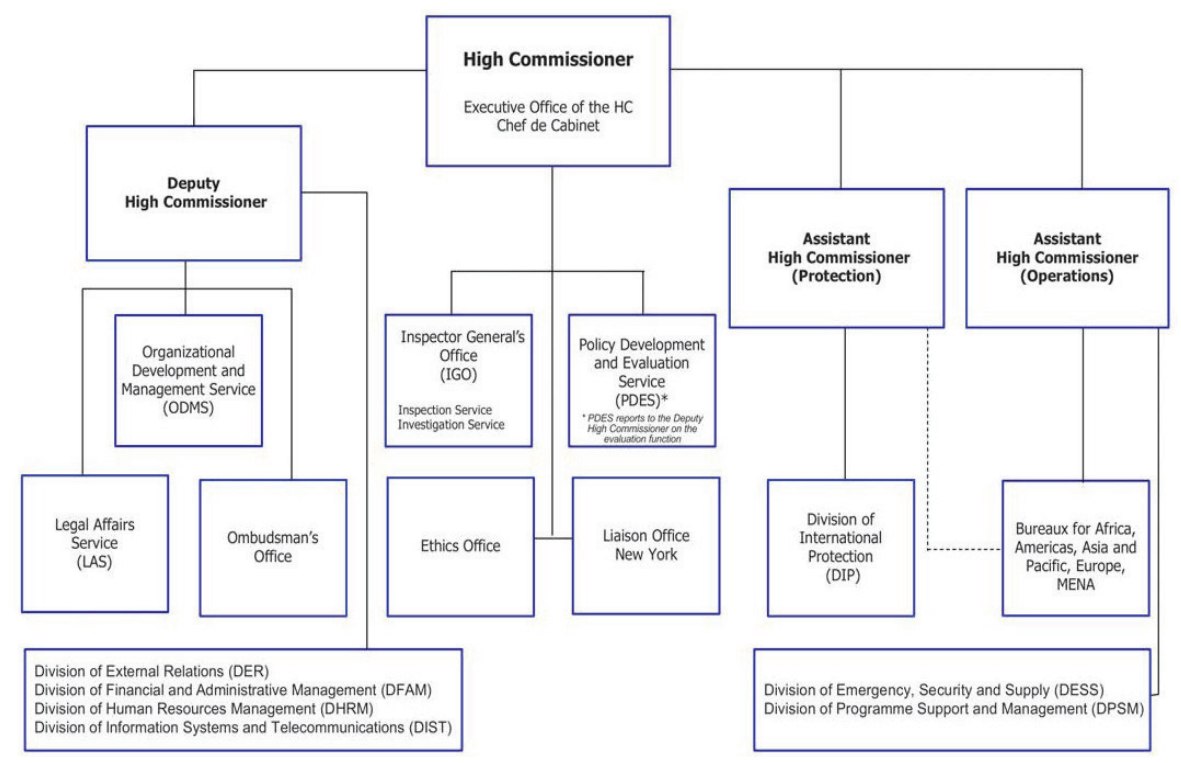

Figure 5. Executive direction and management of UNHCR

The organizational culture among humanitarians should be assessed and changed if necessary. Changes that culture suffers can be positive or negative, so it is important to make sure that the changes are monitored and, if necessary, directed.

\section{Organizational culture and humanitarian cooperation}

In order to deliver effective crisis response operations, an increasing number of individuals, groups, organizations, and jurisdictions need to coordinate their actions. Thus, organizational culture could affect the way different actors perceive the interaction network influencing the process of seeking, trusting, and interpreting emergency information. [Prakash et al., 2020; Mutebi et al., 2020] To be able to establish and implement effective emergency management strategies it is required to perceive the differences among organizations and differences in understanding of the interaction networks. In an emergency, organizational culture affects the perception of humanitarians towards the interpretation of situations, tasks organizing, and interaction with others. Therefore, organizational culture plays a $\mathrm{cru}^{-}$ cial role in the humanitarian supply chain and humanitarian operations by affecting the way different actors give an interpretation to the critical situation. 


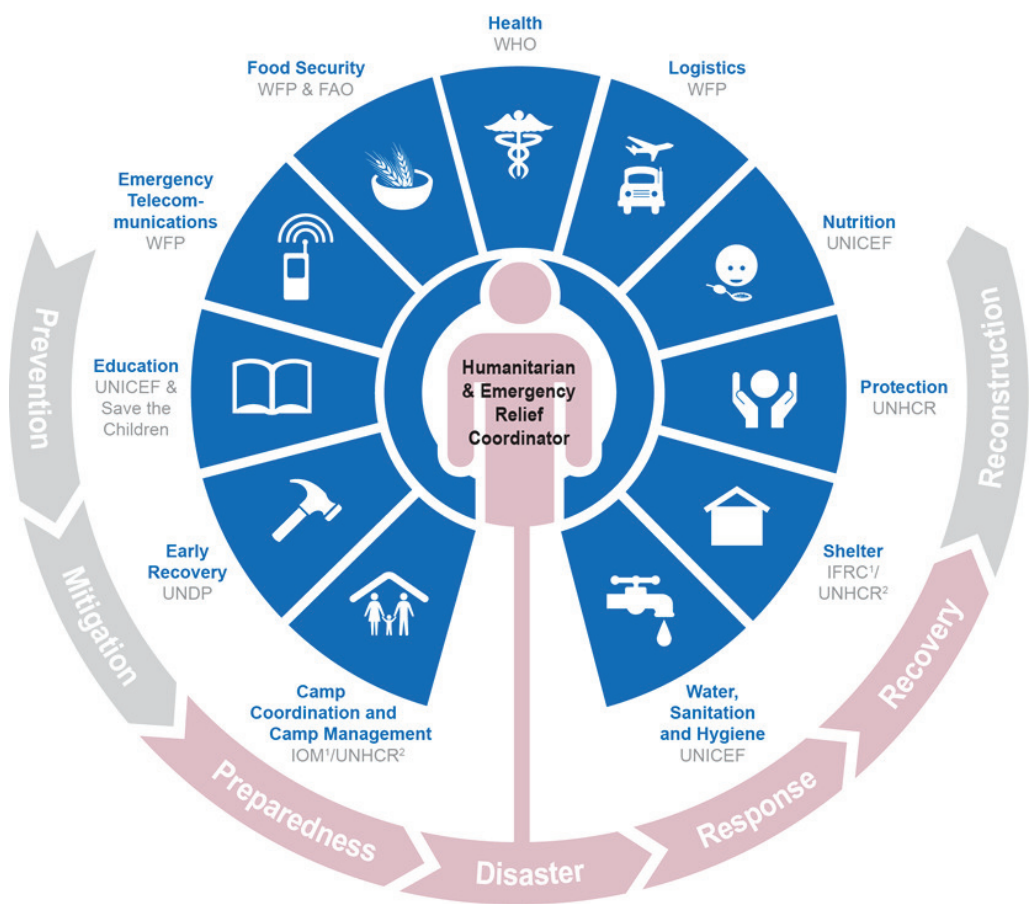

Figure 6. Cluster approach

To illustrate the complexity of the humanitarian sector The Cluster approach is presented. The foundations of the current international humanitarian coordination system were set by General Assembly resolution 46/182 in December 1991. In 2005 , a major reform of humanitarian coordination, known as the Humanitarian Reform Agenda, introduced a number of new elements to enhance predictability, accountability, and partnership. The Cluster Approach was one of these new elements. Clusters are groups of humanitarian organizations, both $\mathrm{UN}$ and non-UN, in each of the main sectors of humanitarian action, e.g. water, health, and logistics. They are designated by the Inter-Agency Standing Committee (IASC) and have clear responsibilities for coordination. Successful application of the cluster approach will depend on all humanitarian actors working as equal partners in all aspects of the humanitarian response: from assessment, analysis and planning to implementation, resource mobilization, and evaluation (IASC, 2006). As it can be seen in figure 6 , the whole humanitarian cluster approach includes an abundance of organiza- 
tions. It depicts the complexity of humanitarian actions and emphasizes the need of establishing strong connections. Every organization has its own organizational structure and culture. This emphasizes the importance of values and beliefs uniformity, strong bonds among them, and the culture that unites all participants towards one goal, to save lives and belongings of beneficiaries.

The humanitarian coordination mechanism consists of more than just "humanitarian" organizations, such as the donors, aid agencies, media agencies, NGOs, governments, militaries, logistics service providers, suppliers, and aid recipients. [Kovacs \& Spens 2008; Van Wassenhove 2006; Oloruntoba \& Gray 2006] Some of them could be without any previous experience in the field. Thus, organizational culture is important for the relationship between different organizations involved in the supply chain of humanitarian aid, because by sharing the same values and views on humanitarian action, the right goals are achieved faster. In the humanitarian area, it means the timely saving of the health and lives of people and their property. Cross-sector humanitarian-business partnerships [Aćimović et al., 2020] make the organizational culture issue more complex. These co- $^{-}$ operations have to be successful because of the importance of the purpose they are established for, protection of human lives and health. Therefore the maximum effort needs to be invested in solving the differences in cultural patterns and frames these organizations have. Therefore, there is a need for teams that are consisted of people from both types of organizations. Additionally, some disasters need the involvement of military forces of the affected country or foreign forces to conjoin the efforts with humanitarian organizations through civil-military coordination to solve the crisis caused by the disaster. [Reis, 2018] Thus, there need to exist principles on which cooperation is based to bridge the cultural gap among partners.

\section{Conclusion}

Organizational culture is an important factor in humanitarian assistance and serves as the glue that sticks an organization together. Strong organizational culture can lower disaster risk and improve the overall performance of an organization. Many researchers have studied this field and a plethora of different approaches have emerged. Some of them are mentioned above and it could be seen that all of them show how important organizational culture is for an organization. 
To improve response abilities when a disaster situation occurs, humanitarian organizations need wellorganized employees and volunteers. Volunteers, as an external workforce, are a very important part of humanitarian response, but they need to follow the rules established by the organization they do the volunteering work for. To follow those rules they need to be aware of the organizational culture, to foster a sense of belonging and the sense of the lives-saving job. But sometimes the staff is not aware of

\section{References}

Aćimović, S., Mijušković, V., Marković, D. \& Milošević, N. (2020). The importance of post-disaster hu-manitarian aid distribution flows in humanitarian logistics. 33rd EBES International Conference, Madrid, Spain. pp. 536546.

Cameron, K.S. \& Quinn, R.E. (2006). Diagnosing and changing organizational culture: Based on the competing values framework. Revised edition. Jossey-Bass, Inc. San Francisco, USA.

Chester, D.K., Duncan, A.M. \& Dibben, C.J. (2008). The importance of religion in shaping volcanic risk perception in Italy, with special reference to Vesuvius and Etna. Journal of $\mathrm{Vol}^{-}$ canology and Geothermal $\mathrm{Re}^{-}$ certain aspects of the culture that affect their behavior. Additionally, organizational culture is important for cooperation and coordination among participants involved in providing humanitarian assistance. To be able to provide assistance smoothly and effectively there should exist similar principles and values that shape the organizational mission and guide the organization's behavior. Therefore, organizational culture is important for internal structure as well as for external bonds among participants

search, Vol. 172(3-4). pp. 216228.

CHS Alliance, Group URD and the Sphere Project. (2014). Core $\mathrm{Hu}^{-}$ manitarian Standard on Quality and Accountability. Available at: https://cms.emergency.unhcr.org/ documents/11982/44705/The+Cor e+Humanitarian+Standard+on+ Quality+and+Accountability $+\% 2$ 8HAP+International $\% 2 \mathrm{C}+$ People +In+Aid+and+the+Sphere+Proje ct\%29/53da61c9-7686-4458-b043Ofb441798338

Cohn, L., Macfarlane, S., Yanez, C. \& Imai, W. (1995). RiskPerception: Differences Between Adolescents and Adults. Health psychology, Vol. 14(3). pp. 217222. 
Milošević $N$. et al., The Importance of Organizational Culture for Humanitarian Operations

Hewitt, B. (2012). The Routledge Handbook of Hazards and Disaster Risk Reduction: Culture, Hazard and Disaster. Routledge. London, UK.

Hilhorst, D. \& Schmiemann N. (2002). Humanitarian Principles and Organisational Culture: Everyday Practice in Médecins Sans Frontières-Holland. Development in Practice, Vol. 12(3). pp. 490-500.

Hofstede, G., Neuijen, B., Ohayv, D.D. \& Sanders, G. (1990). Measuring organizational cultures: a qualitative and quantitative study across twenty cases. Administrative Science Quarterly, Vol. 35. pp. 286-316.

IASC (2006). Guidance Note on Using the Cluster Approach to Strengthen Humanitarian Response. Available at: https://interagencystandingcom mittee.org/system/files/202103/Guidance $\% 20$ Note $\% 20$ on $\% 20$ Using\%20the \%20Cluster\%20App roach $\% 20$ to $\% 20$ Strengthen $\% 20 \mathrm{H}$ umanitarian\%20Response.pdf

ICRC (1986). The Fundamental Principles of the International Red Cross and Red Crescent Movement. Available at: https://www.icrc.org/en/doc/resou rces/documents/red-crosscrescentmovement/fundamental- principles-movement-1986-1031.htm

Inter-Agency Standing Committee (IASC) (2006). Guidance note on using the cluster approach to strengthen humanitarian response.

IOM. IOM organizational structure. Available at:

https://www.iom.int/organization al-structure

Johnson, G., Whittington, R. \& Scholes, K. (2012). Fundamentals of strategy. 2nd edition. Pearson Education Limited. Edinburgh, UK.

Johnson, K., Wahl, D. \& Thomalla, F. (2016). Addressing the cultural gap between humanitarian assistance and local responses to risk through a place-based approach. Project: SEI Asia Centre Research Cluster on Reducing Disaster Risk.

Kovacs, G. \& Spens, K. (2008). Northern lights in logistics and supply chain management: $\mathrm{Hu}^{-}$ manitarian logistics revisited. CBS Press. Copenhagen, Denmark.

Kruks-Wisner, G. (2010). Seeking the local state: Gender, caste, and the pursuit of public services in post-tsunami India. World Development, Vol. 39(7). pp. 1143-1154. 
Kwantes, C.T. \& Boglarsky, C.A. (2004). Do occupational groups vary in expressed organizational culture preferences? A study of six occupations in the United States. International Journal of Cross-Cultural Management [Special Issue: Identifying Culture], Vol. 4. pp. 335-353.

Louis, M.R. (1985). An Investigator's Guide to Workplace Culture. Organizational Culture. Sage. Beverly Hills, USA.

Martin, J. \& Siehl, C. (1983). Organizational Culture and Counterculture: An Uneasy Symbiosis. Organizational Dynamics, Vol. 12(2). pp. 52-64.

Mutebi, H., Ntayi, J., Muhwezi, M., Munene, J. (2020). Self-organisation, adaptability, organisational networks and inter-organisational coordination: empirical evidence from humanitarian organisations in Uganda. Journal of Humanitarian Logistics and Supply Chain Management, Vol. 10(4). pp. 447-483.

Oloruntoba, R. \& Gray, R. (2006). Humanitarian aid: An agile supply chain? Supply Chain Management, Vol. 11(2). pp. 115-120.

Paradise, T.R. (2005). Perception of earthquake risk in Agadir, Morocco: a case study from a Muslim community. Global Envi- ronmental Change Part B Environmental Hazards, Vol. 6(3). pp. 167-180.

Pettigrew, A.M. (1979). On Studying Organizational Cultures. Administrative Science Quarterly, Vol. 24(4). pp. 570-581.

Prakash, C., Besiou, M., Charan, P., Gupta, S. (2020). Organization theory in humanitarian operations: a review and suggested research agenda. Journal of Humanitarian Logistics and Supply Chain Management, Vol. 10(2). pp. 261-284.

Reis, F.A. (2018). Military Logistics in Natural Disasters: The Use of the NATO Response Force in Assistance to the Pakistan Earthquake Relief Efforts. Contexto Internacional, Vol. 40(1). pp. 73-96.

Renn, O. \& Rohrmann, B. (2000). Cross-Cultural Risk Perception: State and Challenges. Springer. Boston, USA.

Righi, E., Lauriola, P., Ghinoi, A., Giovannetti, E. \& Soldati, M. (2021). Disaster risk reduction and interdisciplinary education and training. Progress in Disaster Science, Vol. 10. pp. 1-16.

Robbins, S.P. \& Coulter, M. (2005). Management. 8th edition. Pearson Prentice Hall. New Jersey, USA. 
Milošević $N$. et al., The Importance of Organizational Culture for Humanitarian Operations

Robbins, S.P. \& Judge, T.A. (2012). Organizational Behavior. Pearson Prentice Hall. New Jersey, USA.

Schein, E. (2004). Organizational Culture and Leadership. 3rd edition. Jossey-Bass, Inc. San Francisco, USA.

Schwartz, H.M., Davis, S.M. (1981).

Matching corporate culture and business strategy. Organizational Dynamics. Vol. 10 (1). pp. 30-48.

Scott-Findlay, S., Estabrooks, C.A. (2006). Mapping the organizational culture research in nursing. A literature review. Journal of Advanced Nursing, Vol. 56(5). pp. 498-513.

Sikorski C. (2003). Zapamiętane z dzieciństwa. Szkice o kulturze organizacyjnej. Wydawnictwo Wyższej Szkoły HumanistycznoEkonomicznej. Łódź, Poland.

Sphere Association. (2018). The Sphere Handbook: Humanitarian Charter and Minimum Standards in Humanitarian Response, 4th edition. Geneva, Switzerland.

Szczepańska, K. \& Kosiorek, D. (2017). Factors influencing organizational culture. Scientific Papers of Silesian University of Technology. Organization and
Management Series. pp. 457468.

UN (2018). United Nations Disaster Assessment and Coordination - UNDAC Field Handbook. Available at:

https://www.unocha.org/sites/uno cha/files/1823826E_web_pages.p $\underline{\mathrm{df}}$

UNHCR (2014). UNHCR Global Ap-peal 2014-2015 - Operational support and management. Available at:

https://www.unhcr.org/publicatio ns/fundraising/528a0a380/unhcrglobal-appeal-2014-2015-

operational-supportmanagement.html

UNOCHA. What are Humanitarian Principles? Available at: https://www.unocha.org/sites/dm s/Documents/OOMhumanitarianprinciples_eng_Jun e12.pdf

Van Wassenhove, L.N. (2006). Humanitarian aid logistics: Supply chain management in high gear. Journal of the Operational Research Society, Vol. 57(5). pp. 475-489.

Walkup, M. (1997). Policy Dysfunction in Humanitarian Organizations: The Role of Coping Strategies, Institutions, and Organizational Culture. Journal of Refugee Studies, Vol. 10 (1). pp. 37-60. 


\title{
ZNAČAJ ORGANIZACIONE KULTURE ZA HUMANITARNE OPERACIJE
}

\author{
Nikola Miloševićn ${ }^{1}$, Milan Mišiće 2 , Nemanja Matić ${ }^{3}$ \\ ${ }^{1}$ RMHK Trepča A.D., Zvečan \\ ${ }^{2}$ Akademija strukovnih studija Kosovsko Metohijska, Leposavić \\ ${ }^{3}$ Delikos DOO, Sopot
}

Korespondencija: nikolamilosevic1@yahoo.com

Rezime. Humanitarno okruženje postavlja niz izazova za organizcije, pa je važno odgovoriti na adekvatan način. Organizaciona kultura je važan faktor u organizacionim performansama i može biti odlučujući faktor između uspeha i neuspeha. Svaka organizacija ima svoju jedinstvenu kulturu, bilo da je menadžment toga svestan ili ne. Da bi funkcionisale na najefikasniji način i bile u mogućnosti da realizuju strategiju, humanitarnim organizacijama je potrebna odgovarajuća i jaka organizaciona kultura. Zatim, kako bi se ojačao osećaj da tim ima svrhu svog postojanja i kako bi se pomoglo članovima da deluju i razmišljaju u istom pravcu, razvijeni su humanitarni principi i standardi. Za razvoj organizacije veoma je važno pravovremeno uspostavljanje sistema vrednosti i obrazaca ponašanja. Organizaciona kultura je važna kako za unutrašnju strukturu, tako i za veze među učesnicima.

Ključne reči: organizaciona kultura, humanitarna organizacija, saradnja, humanitarne operacije 
